\title{
PROJETO DE VIDA NO DISCURSO DE JOVENS MÚSICOS ${ }^{1}$
}

\author{
Aline Moreira Gonçalves \\ Marcos Vieira-Silva \\ Marília Novais da Mata Machado"
}

\begin{abstract}
RESUMO. Investiga-se o que é a música para jovens músicos de São João Del Rei, cidade da região do Campo das Vertentes, Minas Gerais, que convive cotidianamente com bandas e orquestras bicentenárias e onde o fazer musical é forte referência na vida das pessoas, especialmente na de crianças e adolescentes. Tendo-se como referencial teórico a psicossociologia e suas noções de imaginário social, projeto de vida e grupo como sistema cultural, simbólico e imaginário, foram entrevistados 21 jovens vinculados a corporações musicais da cidade. As entrevistas transcritas passaram por procedimentos derivados da análise arqueológica do discurso. Buscou-se explicitar o papel da atividade musical na construção de projetos de vida dos jovens, isso é, nas modalidades de inserção social desses sujeitos no contexto de sua realidade, suas formas de projetar o futuro e lançar-se em busca de algo a ser realizado.
\end{abstract}

Palavras-chave: Projeto de vida; adolescentes; músicos.

\section{LIFE PROJECT IN THE SPEECH OF YOUNG MUSICIANS}

\begin{abstract}
It was searched what music is for young musicians in São João del Rei, a city in the region of Campo das Vertentes, Minas Gerais, that daily lives with brass bands and bicentennial orchestras and where the musical activities are a strong reference in peoples lives, specially among children and teenagers. Adopting the psycho-sociological theory and its notions of social imaginary, life project and group as a cultural, symbolic and imaginary system, 21 young people from musical corporations in the city were interviewed. The transcribed interviews were submitted to procedures derived from archeological discourse analysis. It was tried to make explicit the role of musical activity in the youth's life project building, that is, the modalities of social insertion of these subjects in their reality, their ways of projecting the future and of throwing themselves in the search of something to be realized.
\end{abstract}

Key words: Life project; adolescents; musicians.

\section{PROYECTO DE VIDA EN EL DISCURSO DE LOS JÓVENES MÚSICOS}

RESUMEN. Se ha investigado lo que es la música para jóvenes músicos de São João Del Rei, ciudad de la región de Campo das Vertentes, Minas Gerais, que convive cotidianamente con bandas y orquestas bicentenarias y donde el hacer musical es una fuerte referencia en la vida de las personas, especialmente de los niños y adolescentes. Teniendo como referencial teórico la psico sociologia y sus conceptos de imaginario social, proyecto de vida y grupo como sistema cultural, simbólico e imaginario, han sido entrevistados 21 jóvenes vinculados a las corporaciones musicales de la ciudad. Las entrevistas transcritas han sido sometidas a procedimientos derivados del análisis arqueológico del discurso. Se ha buscado explicitar el papel de la actividad musical en la construcción de proyectos de vida de los jóvenes, es decir, en las modalidades de inserción social de estos sujetos en el contexto de su realidad, sus formas de proyectaren el futuro y de se lanzaren en busca de algo a ser realizado

Palabras-clave: Proyecto de vida; adolescente; músicos.

1 Apoio: CNPq/ FAPEMIG.

Psicóloga pela Universidade Federal de São João del Rei, cursando mestrado em Psicologia Social pela Universidade Federal de Minas Gerais.

\# Doutor em Psicologia Social pela Pontifícia Universidade Católica de São Paulo. Professor Associado da Universidade Federal de São João del-Rei e coordenador do Laboratório de Pesquisa e Intervenção Psicossocial - LAPIP.

II Doutora em Psicologia Social pela Universidade de Paris XIII (Paris Norte), com pós-doutorado em Psicologia na Universidade Federal de São João del Rei, onde atualmente é Professora Visitante Nacional Sênior(PVNS/ Capes). 
A região do Campo das Vertentes, em Minas Gerais, especialmente São João del Rei e cidades circunvizinhas, convivem cotidianamente com bandas e orquestras bicentenárias cujos membros vêm dos mais diversos grupos socioculturais. $\mathrm{O}$ primeiro registro da atividade musical na região data de 1717 , quando Dom Pedro de Almeida Portugal, Conde de Assumar, foi recebido na Vila de São João Del Rei ao som de uma música regida pelo maestro Antônio do Carmo Sobrinho. Desde então, ordens religiosas e políticas solicitam a presença da música nas festividades, o que viabiliza a continuidade da atividade musical na região até os dias atuais. Durante o séc. XVIII essa atividade garantia a sobrevivência de seus atores, que faziam dessa prática uma profissão. A identidade coletiva de músico se revestia, então, de importância e tradição cultural (Gonçalves \& VieiraSilva, 2009).

As mais antigas corporações musicais de São João del Rei são as bicentenárias orquestras Lira Sanjoanense e Ribeiro Bastos. Conforme Sobrinho (2002), a primeira surgiu em 1776 e foi denominada Companhia de Música, e a segunda surgiu em 1790, com o nome de Partido da Música.

No séc. XIX, no bojo da diversificação da economia mineira, os músicos passaram a ser malremunerados e, por isso, começaram a buscar outras formas de inserção no cenário socioeconômico local. O pesquisador Gallo (1998) aponta, em sua monografia intitulada "Coalhadas e Rapaduras: história social da música em São João del Rei no séc. XIX”, que a música deixou, então, de ser a única fonte de sobrevivência para os que a ela se dedicavam. Para esse autor, a cor da pele diferenciada ("coalhadas e rapaduras") era uma realidade dentro das principais corporações musicais. Para ele, o exercício da música, inicialmente, proporcionou uma distinção para os mulatos, então depreciados e excluídos no cenário de uma sociedade escravocrata. Depois, ao se apropriarem da arte, os mulatos ascenderam a uma classe superior e esse "embranquecimento" os impulsionou a desenvolver um sólido acervo musical que se tornou referência para toda a região (Gallo, 1998).

Na segunda metade do séc. XIX, a atividade musical de São João del Rei intensificou-se, a cidade ficou conhecida como "cidade da música" e os músicos são-joanenses passaram a ser convidados a tocarem em outras cidades e a ensinarem sua arte. Nessa mesma época, surgiram a Orquestra Ramalho, de Tiradentes, e a Orquestra Lira Ceciliana, da cidade vizinha Prados. Porém, com a diminuição das riquezas e a diversificação da economia mineira daquele século, parte das orquestras e bandas se estagnou ou regrediu até o seu fim. Mesmo assim, a música continuou a ser um diferencial social e, segundo Gallo (1998), muitos ainda investem nessa carreira que leva à ascensão social.

Também na segunda metade do séc. XIX surgiram as bandas musicais da região dos Campos das Vertentes, a partir das orquestras já consolidadas. Então, "o novo se instala e os oitocentos pode ser considerado o século das bandas e de seu repertório típico" (Gallo, 1998, p. 27). As bandas se dedicaram principalmente à música secular, ampliando e diversificando o repertório musical da região, o qual, dessa forma se popularizou. Elas instauraram um movimento claramente percebido de manutenção e transformação da tradição, incrementado pelo fato de muitas delas manterem, paralelamente às suas atividades, uma escola de música para crianças e adolescentes. A banda-escola, na maioria das vezes, permite o primeiro contato técnico com instrumentos musicais (Gonçalves \& Vieira-Silva, 2009).

Os membros das corporações mais novas, especificamente das bandas de música, são majoritariamente crianças e adolescentes na faixa etária entre dez e dezenove anos. A atividade musical torna-se, então, uma referência para esses jovens e, muitas vezes, ao abrir a possibilidade de atividade profissional futura, contribui para fazer nascerem projetos de vida. Sendo assim, a consideração da confluência de vivências, vínculos afetivos e subjetividades nos grupos musicais justifica $\mathrm{o}$ interesse em investigar, especialmente entre músicos mais jovens participantes das corporações musicais, o papel da atividade musical na construção de seus projetos de vida, objeto da investigação aqui apresentada.

Do latim projectu, particípio passado do verbo projicere, a palavra projeto significa lançar-se para diante, para frente; evoca mudança, movimento, empreendimento pessoal, esboço de futuro. $\mathrm{O}$ projeto de vida alude a aspirações e desejos do jovem músico e, em caso de um projeto coletivo, aspirações e desejos do grupo, organização, comunidade ou sociedade. A partir dessa definição de projeto de vida como atividade imaginária e instituinte, o objetivo da pesquisa é conhecer o que representa a música para essas crianças e adolescentes vinculados a grupos musicais, a importância (ou não) dela para a construção de seus projetos de vida, sua função norteadora (ou não) da autonomia desses sujeitos sociais. A investigação é feita por meio da análise de discursos relativos à prática que iguala esses jovens como membros de um grupo e, ao mesmo tempo, os diferencia dos outros jovens de mesma faixa etária no cenário social-histórico do qual fazem parte. 


\section{REFERENCIAL TEÓRICO: O IMAGINÁRIO SOCIAL E O PROJETO DE VIDA}

As teorias de Castoriadis (1982, 1999, 2007, 2008) sobre o imaginário radical e a autonomia são pertinentes para a pesquisa do projeto de vida. Para esse filósofo, o sujeito é capaz de autoatividade construtiva, de imaginariamente instituir algo. A capacidade de criar o próprio mundo caracteriza o ser vivo, mas o que diferencia o ser humano dos outros viventes é a imaginação radical que, além da capacidade de fazer ser o que não é no mundo simplesmente físico e de se representar à sua própria maneira, é constantemente criadora, fluxo espontâneo e incontrolável de representações, de afetos e de desejos, liberado de sua finalidade biológica (Castoriadis, 1999). O imaginário cria a sociedade e suas instituições, assim como cria projetos sociais e individuais que, quando dirigidos à autonomia, surgem como um germe que se volta para a garantia da participação efetiva dos sujeitos na sociedade, para o questionamento de significações imaginárias sociais já instituídas, para o incremento da capacidade instituinte de gerar o novo.

A noção castoriadiana de imaginário radical foi adotada e desdobrada por Enriquez (1997, 2008), para quem todo conjunto social, grupo, comunidade ou sociedade é simultaneamente um sistema cultural, simbólico e imaginário. Essa teoria - a psicossociologia - permite lançar luz sobre as corporações musicais enquanto grupos. Como sistema cultural, corporações musicais são portadoras de uma cultura, isto é, de uma estrutura de valores e normas, de uma maneira de pensar, de um modo de apreensão do mundo e de representações sociais historicamente construídas e interiorizadas que orientam a conduta de seus membros. Sistemas culturais são responsáveis pela atribuição de lugares aos diversos membros, pelas expectativas de papéis, pelas condutas mais ou menos estáveis, pelos hábitos de pensamento e ações que facilitam a construção de uma obra coletiva. Assim, os grupos musicais desenvolvem um processo de formação e de socialização dos seus membros de tal forma que cada um se define de acordo com o ideal proposto por eles e adota os comportamentos e as atitudes tidas como boas pelo grupo. Esses aspectos da cultura podem ser coerentes entre si ou entrarem em contradição uns com os outros, mas são indispensáveis no estabelecimento e manutenção do grupo, pois são eles que garantem a identidade grupal e de cada um de seus membros. Como sistema simbólico, nenhum grupo pode viver sem mitos unificadores, sem ritos de iniciação, de passagem e de realização, sem heróis fundadores reais ou imaginários -, sem uma saga para servir de memória coletiva (Enriquez, 1997). Mitos, ritos e heróis sedimentam a ação dos membros, dão um sentido às suas práticas e vidas, transformam o grupo num objeto que pode ser mostrado, com orgulho, a outros atores sociais. Como sistema imaginário, o grupo consegue se estabelecer como cultura e símbolo. Enriquez $(1997,2001)$ sugere que todo projeto é construído no imaginário, podendo ser motor ou enganoso. É motor quando o sujeito toma consciência de seu desejo de realizá-lo, é impulsionado a se movimentar nessa direção e reconhece não apenas o seu próprio desejo, mas também o desejo de seu grupo ou de sua coletividade; e é enganoso quando o sujeito, pautado somente em idealizações, crenças e/ou ilusões, não questiona nem realiza movimentos no sentido da concretização de seu projeto, da construção de sua identidade ou do exercício de sua autonomia, imergindo na massa, sem se diferenciar, ou quando se perde em seus desejos narcísicos.

A análise das corporações na perspectiva dos três sistemas propostos por Enriquez (1997, 2008), especialmente do sistema imaginário, permite avaliar se os projetos de vida de seus membros são construídos articulados ao fazer musical, às identidades coletivas das corporações ou às identidades das crianças e adolescentes envolvidos nesse processo grupal. Nessa construção, pode atuar o imaginário motor. Segundo Enriquez (1997), esse imaginário atua ao lado de um projeto construtivo e na raiz das utopias e das práticas sociais inovadoras. Ele permite escapar das rotinas cotidianas e estabelecer novos ritmos de vida, dinâmicas de trabalho e relações sociais favorecedoras da criatividade, da palavra livre, do pensamento questionador, do humor, da frivolidade; ele desafia as regras de funcionamento que regem a sociedade, mesmo as mais flexíveis.

Num projeto regido pelo imaginário motor, o sujeito se lança em algo novo, desconhecido, e procura seu próprio caminho, mesmo que não ganhe sempre, que enfrente derrotas, perdas, sujeições e recuos. Nesse projeto, o sujeito está implicado em sua alteridade, sendo capaz de reconhecer-se como responsável por seu destino, portanto, também de realizar mudanças, mesmo que mínimas, no contexto social em que está inserido. Ao tornar-se questionador e crítico, ele torna-se capaz de construir, ativa e realisticamente, seu projeto de vida; é um ator social, criador de sua própria história e também da história coletiva e tece sua identidade por meio de processos de subjetivação fecundos.

Por outro lado, caso o sujeito, sem se questionar, dobre-se ao imaginário enganoso, numa sociedade que exige indivíduos proativos e pessoalmente diferenciados, ele pode responder a essas exigências 
sem se reconhecer nessa diferenciação, colocando-se ao lado da repetição, da ritualização e da morte.

Os três sistemas propostos por Enriquez (1997, 2008) o cultural, o simbólico e o imaginário - estão sempre presentes nas organizações, assim como o imaginário motor e o enganoso, sendo muitas vezes impossível e/ou desnecessária a distinção entre eles. É importante ressaltar que, de toda forma, o sujeito se constitui no imaginário antes de qualquer realização concreta.

\section{OS ENTREVISTADOS E SEU CONTEXTO SOCIAL-HISTÓRICO}

Os sujeitos entrevistados nesta pesquisa são crianças e adolescentes, músicos e musicistas que participam de corporações musicais e tocam ao menos um instrumento. Em alguns casos, esses jovens participam ao mesmo tempo de mais de uma corporação. São de classe social baixa ou média, moram na periferia da cidade e estudam em escolas públicas. A única atividade extracurricular que realizam é a participação no grupo musical e, em alguns casos, o curso do conservatório estadual de música existente na cidade. Eles fazem parte de uma das duas maiores bandas da periferia da cidade. Uma delas tem aproximadamente três anos de existência e a outra é um pouco mais antiga. As duas bandas mantêm escolinhas de música com o intuito de iniciar crianças no aprendizado musical. Na maior parte das vezes, os professores dessas escolas informais são também membros da banda e, por serem experientes em algum instrumento, são convidados pelos regentes a ministrarem aulas. Esses monitores trabalham como voluntários, lecionando gratuitamente. Dois deles, hoje com dezenove anos, cursam a graduação em música pela Universidade Federal de São João del Rei (UFSJ) e fazem dessa atividade uma aliada de seus estudos. A iniciação musical de muitos dos entrevistados nasce dentro da própria família. Pode-se dizer que essa característica deriva do fato de a atividade musical ser uma tradição na região, passada de geração a geração e mantida com a renovação de práticas e costumes antigos. Um conjunto de performances musicais está sempre sendo aperfeiçoado e apropriado coletivamente. $\mathrm{O}$ incentivo para os jovens continuarem na atividade musical, muitas vezes, aparece dentro da família, principalmente da parte das mães. A fala de um dos entrevistados, R., aponta os diversos fatores associados à entrada dos jovens no mundo da música, que incluem as oportunidades e aberturas oferecidas pelas corporações e o incentivo materno:

\begin{abstract}
“É... O papel acho que não só o da orquestra Ribeiro Bastos, mas de todas as corporações de São João é justamente é... estar sempre dando chance para os jovens, às vezes é não só a orquestra, mas as bandas também já revelaram muitos músicos, a maioria dos músicos bons, pelo menos que eu conheço. A maioria dos músicos bons daqui de São João ou já tocou na banda ou já tocou na orquestra. É tudo assim, eu acho que às vezes eu lembro que minha mãe falava que, ainda bem que você está na música, porque se você não tivesse na música você podia ta na rua. Acho que esse também é um papel muito importante, não só da orquestra, mas das corporações de São João inteiras (...)".
\end{abstract}

\section{MÉTODO}

Para a coleta das informações, além daquelas já apresentadas na introdução relativas ao contexto social-histórico estudado, obtidas, em grande parte, em Gonçalves e Vieira-Silva (2009), foram realizadas quinze entrevistas com crianças e adolescentes entre dez e dezenove anos, sendo 14 individuais e uma coletiva. As entrevistas seguiram um roteiro semiestruturado que incluiu questões relativas à tradição musical em São João del Rei, à inicialização musical e à representação de cada jovem entrevistado sobre ser músico/mucisista, ao papel social das bandas, à participação grupal, aos valores e crenças relacionados ao fazer musical e à construção de projetos de vida. Elas foram realizadas por uma bolsista de iniciação científica e, sob supervisão dela, por dois alunos do Ensino Médio, músicos, que receberam bolsa de iniciação científica júnior pela UFSJ. No total, foram entrevistados vinte e um sujeitos. As entrevistas foram gravadas e transcritas a fim de se proceder às análises. Um termo de consentimento livre e esclarecido foi assinado por todos os entrevistados e, no caso dos menores de dezoito anos, também por seus responsáveis.

Para análise das entrevistas utilizaram-se procedimentos inspirados na análise do discurso (Charaudeau, 2008; Courtine, 2009; Gregolin, 2006; Maingueneau, 2007, 2008), especialmente na análise arqueológica proposta por Foucault $(2008,2010)$ e detalhada por Machado (2009). Buscou-se a realização de uma descrição ou de uma reescrita do discurso desses sujeitos sobre os seus projetos de vida, acentuando dispersões, rupturas e descontinuidades. $\mathrm{O}$ termo arqueologia: 
Não incita à busca de nenhum começo; não associa a análise a nenhuma exploração ou sondagem geológica. Ele designa o tema geral de uma descrição que interroga o jádito no nível de sua existência: da função enunciativa que nele se exerce, da formação discursiva a que pertence do sistema geral de arquivo de que faz parte. A arqueologia descreve os discursos como práticas especificadas no elemento do arquivo (Foucault, 2008, p. 151).

Fazer a análise arqueológica dos discursos dos jovens músicos, nesta pesquisa, é apontar, numa multiplicidade de aspectos, o que não é e o que é, para eles, a música:

\begin{abstract}
A análise arqueológica revela o primado de uma contradição que tem seu modelo na afirmação e na negação simultânea de uma única e mesma proposição, mas não para nivelar todas as oposições em formas gerais de pensamento e pacificá-las à força por meio de um a priori coator. Trata-se, ao contrário, de demarcar, em uma prática discursiva determinada, o ponto em que elas se constituem, definir a forma que assumem, as relações que estabelecem entre si e o domínio que comandam. Em suma, trata-se de manter o discurso em suas asperezas múltiplas (Foucault, 2008, p. 179).
\end{abstract}

A análise considerou as articulações entre texto e contexto. $\mathrm{O}$ texto refere-se às falas transcritas dos entrevistados. O conjunto das entrevistas forma o arquivo da pesquisa. Cada transcrição é um corpus, ou seja, uma unidade empírica sobre a qual a análise é realizada. O contexto refere-se ao que Foucault designa como prática discursiva, isto é, ao "conjunto de regras anônimas, históricas, sempre determinadas no tempo e no espaço, que definiram, em uma dada época e para uma determinada área social, econômica, geográfica ou linguística, as condições do exercício da função enunciativa" (Foucault, 2008, p. 136).

Neste caso, as informações de contexto levaram em conta não apenas a história da música em São João Del Rei e região, mas também a dos atores hoje inseridos nessa realidade, tendo como marco inicial a sociedade sanjoanense do séc. XVIII. Perguntou-se qual é o sentido da música para esses jovens, o que é e o que não é essa atividade para eles. Ao final da pesquisa, chegou-se a enunciados relativos ao projeto de vida dos músicos. A noção de enunciado, aqui, é definida, com base em Foucault (2008), como:

uma unidade funcional elementar do discurso que não se confunde com a frase gramatical, com a proposição lógica, nem com o ato de fala; que não pode ser apreendida segundo qualquer critério estrutural; que não é um grupamento unitário de signos, nem um sintagma; que não é livre, neutra e independente, mas faz, sempre, parte de uma série ou de um conjunto em que se apóia, do qual participa e se distingue. É, antes, um recorte realizado pelo pesquisador (Machado, 2010, p. 27).

O enunciado, para existir, requer um referencial, um sujeito, um campo associado e uma materialidade:

Examinando um enunciado, o que se descobriu foi uma função que se apóia em conjuntos de signos, que não se identifica nem com a "aceitabilidade" gramatical, nem com a correção lógica, e que requer, para se realizar, um referencial (que não é exatamente um fato, um estado de coisas, nem mesmo um objeto, mas um princípio de diferenciação); um sujeito (não a consciência que fala, não o autor da formulação, mas uma posição que pode ser ocupada, sob certas condições, por indivíduos indiferentes); um campo associado (que não é o contexto real da formulação, a situação na qual foi articulada, mas um domínio de coexistência para outros enunciados); uma materialidade (que não é apenas a substância ou o suporte da articulação, mas um status, regras de transcrição, possibilidades de uso ou de reutilização (Foucault, 2008, p. 133).

O referencial são as falas construídas socialmente em situação de entrevista; os sujeitos são os jovens músicos e seus pares, assim como os entrevistadores (coautores do discurso construído); o campo associado é constituído pelo processo grupal no qual estão todos inseridos, pelas corporações musicais e pela sociedade sanjoanense, com seus vínculos sociais imaginários e reais, sua história e suas tradições; a materialidade é fundada nos corpora construídos, isto é, nas transcrições das entrevistas. $\mathrm{O}$ conjunto de enunciados resultante desta pesquisa refere-se ao discurso dos jovens músicos sobre os seus projetos de vida. Adotase a definição de discurso proposta por Foucault (2008): "para quem discurso é o "conjunto de enunciados que se apóia em um mesmo sistema de formação" (p. 124).

\section{O DISCURSO SOBRE O PROJETO DE VIDA}

A leitura cuidadosa e repetida das entrevistas permitiu conhecer vivências, vínculos afetivos e 
aspectos da subjetividade dos jovens músicos e musicistas entrevistados. Falas, vivências, vínculos e subjetividade permitiram construir enunciados que descrevem o discurso dos jovens músicos sobre seus projetos de vida. Esses enunciados estão apresentados abaixo, assim como alguns exemplos de falas que os evidenciam.

\section{Enunciado 1 - A música distingue socialmente os músicos}

A participação em uma corporação é valorizada socialmente e autoriza os jovens músicos a se sentirem ativos e importantes. Para eles, a atividade musical para eles possibilita uma afirmação da própria identidade social. Assim, a participação na banda alimenta desejos de reconhecimento por parte do outro os colegas de banda e de escola, amigos, parentes e conhecidos - e os leva a valorizar o reconhecimento social que recebem. A participação alimenta também o reconhecimento do próprio desejo de se realizar como pessoa e, muitas vezes, também como músico. Os jovens relatam gostar das apresentações musicais e dizem que, ao tocarem publicamente os seus instrumentos, recebem atenção e respeito.

\begin{abstract}
"Ah... (..), porque você tá parado em casa, sem fazer nada, aí você fala: "Ah, eu estudo na banda." Igual se fala: construir um nome dentro de um grupo é muito importante. E manter isso. (J.)".
\end{abstract}

"Pra mim, assim. Quando eu vou me apresentar, eu me apresento como músico, né? Parece que as pessoas se mostram mais interessadas a perguntar as coisas, e assim eu arrumo mais amizades (L.)".

\begin{abstract}
“Assim, eu gosto de me exibir um pouquinho pras pessoas (risos). Eu fico assim: 'Ah, porque eu sou música, musicista, e eu toco flauta transversal.' Aí eu começo a fazer a minha fama, todo mundo: 'Ali, a AL., musicista, ela toca tal instrumento.' Aí eu gosto." (AL.).
\end{abstract}

\section{Enunciado 2 - A participação nos grupos cria um espaço de socialização}

$\mathrm{O}$ desejo de reconhecimento e o reconhecimento do desejo evidenciados no primeiro enunciado praticamente se confundem com a socialização aqui enunciada, que se distingue pela afetividade, como se vê nas falas dos jovens músicos. Eles fazem música porque gostam disto e por se sentirem inteiramente envolvidos. A participação nos grupos musicais possibilita não só o aprendizado instrumental técnico, mas também um aprendizado pessoal, além de vivências significativas. Numa palavra, a música é um espaço de socialização. Para os entrevistados, tocar em grupo, embora difícil, é atividade importante. Eles afirmam ser a participação grupal um aprendizado do trabalho coletivo, uma experiência que os ajuda pessoal e profissionalmente.

\begin{abstract}
“(...) parte de tocar em grupo é a parte mais importante que às vezes muitos músicos têm dificuldade de tocar em grupo, às vezes toca muito bem sozinho, mas aí vai tocar em grupo fica perdido; então acho que a parte profissional é essa, tocar em grupo, e a parte pessoal acho que é a amizade que a gente sempre faz quando a gente está em algum grupo e fica muito próximo das pessoas, e a gente cria um laço de amizade." (R.).
\end{abstract}

"Eu conhecia pouca gente aqui, mas quando eu entrei na banda eu conheci mais, e... A banda, na verdade, é uma grande família, $e$ mesmo que você esteja brigado com alguém, não gosta em algum momento, você vai ter que respeitar, porque a música pede isso, em certos momentos. E... Aí por isso que eu... eu gosto muito de tá aqui. Além de fazer amizades novas você aprende a respeitar as pessoas, o seu jeito de agir". (J.).

\begin{abstract}
"Assim, porque mais amigos que me conhecem da banda, porque eu sou músico, porque, assim, eu toco há muito tempo, mais de oito anos de música né? E... assim, pra mim quem me conhece mesmo me conhece como músico mesmo. "O E., ele é músico." Os que me conhecem. Aí os que não me conhecem... me perguntam se eu o que eu faço e eu falo: 'Eu sou músico'." (E.)
\end{abstract}

Vê-se, ainda, que a relação dos músicos com os regentes das corporações e com os outros membros do grupo atravessa suas performances. Quando a afetividade se manifesta positivamente na corporação, os entrevistados gostam de aí estar presentes, têm carinho pelo líder do grupo e pelos outros músicos, sentem-se bem quando participam desse clima amistoso. Nesse ambiente, acumulam experiência musical, aprendem tocando e fazem trocas importantes. Essa riqueza de experiências os faz continuar nas corporações. O grupo de pares os influencia e facilita o aprendizado musical. Tocar com gente "boa" os estimula a estudar mais e, consequentemente, a melhorar suas performances.

"Acho que é... ah... uma questão até pessoal. No grupo, acho que tem muitos amigos na orquestra e ... isso influencia muito, porque às vezes você toca com gente boa, às vezes 
seu professor vai e toca alguma coisa com você e isso te estimula a estudar mais e isso é muito bom, trocar experiência, e aí a gente vai se tornando cada vez melhor também". (R.).

"É... educação, claro, respeito, é... assim... às vezes, é... ninguém ali é músico profissional, mas acho que a gente tem que ter atitude... Atitude profissional, porque... por exemplo, como é que você tá tocando $e$, no meio do... da música seu celular toca alto, assim, acho que isso é falta de profissionalismo, e mesmo que ali não tem ninguém profissional, isso é uma coisa que a gente vai aprendendo, que vai servir para o resto da vida. Por exemplo, se você for num lugar que uma orquestra profissional você vai levar uma é... você vai levar um xingo, ou então se bobear você é até mandado embora. E às vezes o regente fica, pega no pé de chegar atrasado. Tem essas coisas, pontualidade" (R.).

"Ah, assim, com a banda sendo um grupo você aprende a respeitar o próximo, ajudar as pessoas, e aprender um pouco mais com a experiência dos outros" (AL.).

\section{Enunciado 3 - A música é uma experiência inefável.}

Para os entrevistados, a música é uma experiência singular, uma atividade que abarca completamente a vida, que possibilita vivências significativas e que é formadora da subjetividade dos jovens músicos. É uma experiência inefável, difícil de ser traduzida em palavras: a fala sobre ela é sempre opaca, sobretudo, para os leigos na atividade musical, como se vê nos exemplos a seguir.

"Ah... Porque é um modo de se... ah, eu me sinto bem tocando, é... ouvindo música... Tipo, dizem que... quem canta e toca... músico reza três vezes. E... a música me traz. é... meu estado de espírito bom. Me deixa mais leve e tal." (J).

“(...) uma emoção muito forte né! Muito bom estar tocando. Você vê que entra em outro mundo. (...) A música é tudo, cara! Sem ela... ah... sem ela acho que eu nem tinha essa capacidade de pensar. A música é tudo! (...) Ah, sei lá. (...) música é uma coisa louca, cara!" (P.).

"Ah... O que eu acho mais importante é que não é só uma coisa... não é só um instrumento, não é só uma coisa, ela preenche, é uma que faz você se sentir cheio é...". (D.).

"É... Eu me sinto um pouco nervoso $e$ especial". (AL.)

\section{Enunciado 4 - A música é objeto de ilusões, idealizações e crenças}

Os entrevistados desenvolvem com a música relações que oscilam entre o imaginário motor, quando a música os leva a posicionamentos pessoais e/ou profissionais realistas, e o imaginário enganoso, que pode estagná-los, colocá-los num estado contemplativo e passivo. Assim, quando $\mathrm{K}$ diz: " $A$ minha vida vai ser só a banda mesmo. Vou tentar fazer curso na banda da aeronáutica, outros cursos.", deixa-se levar por ilusões, crenças e uma idealização excessiva e enganosa sobre o papel da música em sua vida; porém o verbo tentar mostra que ele tem o pé na realidade, isto é, pauta-se também por um imaginário motor, o que é confirmado por outra de suas afirmações: "Dá uma possibilidade de vida. Por exemplo, você, músico, seguir carreira, pode sair da rua, vai se dedicar à música, assim...".

$\mathrm{Na}$ afirmação abaixo, $\mathrm{P}$ faz uma generalização enganosa, pois nem todo praticante de música imerge com a mesma intensidade nessa prática; porém, ao mesmo tempo ele está voltado para o futuro, de uma forma motora:

\footnotetext{
"Com certeza acho que todos que praticam a musicalidade, vamos dizer assim... acho que ele planeja isso para o futuro. (...) Ah, ela me passa tudo, passa paz, harmonia. Igual, às vezes tô meio chateado e tal, ouço uma música e já melhora a autoestima. É... a música é tipo o meu mundo particular. Tenho-a como mundo particular" (P.).
}

Vê-se também a presença do imaginário motor quando $\mathrm{P}$ elogia a música lembrando que ela the trouxe responsabilidade: "Ah é muito bom, porque ai eu posso ter mais responsabilidade, saber o certo ou errado." Ou, ainda, em falas realistas, com noção dos próprios limites, sem qualquer ilusão ou crença enganosa, como: "Pra mim representa assim: eu, antigamente, eu não sabia escutar as pessoas, eu era muito explosivo, brigava à toa... Aí hoje eu sei escutar as pessoas, mas ainda sou meio explosivo..." (L.) e "Sinceramente eu olho a música mais como um hobby, porque não é muito a minha praia, eu não sou um bom músico, eu apenas sei brincar". (M.).

Por outro lado, Ad, vivendo longe do mar e entre montanhas, deixa-se levar por uma idealização juvenil enganosa, sem prever obstáculos, distâncias, vida real, embora a ilusão a mova concretamente a preparar uma 
carreira musical: "Ah, eu quero fazer a minha carreira como música, porque quando eu tiver maior e entrar na marinha, fazer curso na marinha, ajudar a minha irmã." Ad reconhece ainda, de forma concreta, os benefícios que a música lhe trouxe: "Não fazia nada, ficava muito na rua, brincava com os meus colegas... Eu começava a xingar a minha irmã... Minha mãe falava: 'Ih, você tá muito estressada'. E eu melhorei'.

\section{Enunciado 5 - A música é, também, um projeto de vida.}

Embora sempre expressa de uma forma pendular, vê-se que a música é parte do projeto de vida dos jovens entrevistados, como perspectiva profissional e/ou como atividade cotidiana:

\begin{abstract}
"Eu, assim, primeiro eu tenho vontade de fazer faculdade de música, mas não necessariamente primeiro. Fazer o que eu quero e tal, depois usar a música como profissão, porque no mercado de trabalho, dependendo, tirando o quartel, que tem a banda do quartel, mas fora isso é bem complicado no mercado de trabalho ser músico e viver disso. Aí por isso que eu queria ter uma profissão sólida e tal, fazer tudo que eu queria, pra depois fazer faculdade de música." (J.).
\end{abstract}

\begin{abstract}
"Depende muito da pessoa, né, porque quando ela é pequena ela pode aprender música e não gostar, assim... tanto, então ela não vai exercer a profissão. Eu já penso em exercer essa profissão". (AL.).
\end{abstract}

\begin{abstract}
"Acho que só basta querer, porque tem a banda lá, tem possibilidade de entrar, mas não adianta ter a banda e a pessoa não falar: "Ah, eu vou ser músico", aí fica lá sentado no sofá vendo televisão. Aí não adianta. Tem que querer fazer e seguir em frente." (J.).

"Eu vejo que vai muito além de você ser músico, ser a sua profissão, né? É aquilo que você gosta, entendeu?" (W.)
\end{abstract}

Os jovens cooperam nos grupos em que são membros e veem sua participação como importante, mesmo sem receberem um salário que os "segure", como se expressam. Para eles, o que faz com que as corporações continuem a existir e não caiam é a "boa vontade" dos músicos de estar lá, de participar do grupo, de gostar de música.

Mesmo sem serem profissionais, esporadicamente realizam tocatas. Nessas apresentações, são pagos pelo trabalho, o que lhes permite antecipar que a atividade musical não será um projeto profissional, mas uma atividade secundária em suas vidas:

Apesar de eu não ser músico profissional, costumo tocar em alguns lugares em casamentos, nos carnavais... sempre recebo dinheiro; não como um projeto de vida; e o músico estudando nas férias tem condições de viver de música, é fundamental e importante. (W.).

De toda forma, a atividade musical é um diferencial para o futuro desses jovens, é um incentivo para crescerem, amadurecerem e, talvez, profissionalizarem-se. Eventualmente é um emprego, pois há orquestras que pagam para se tocar nelas. $\mathrm{Na}$ região, especialmente para os meninos, há uma possibilidade de futuro como instrumentista dos batalhões do exército:

\begin{abstract}
"Então, eu comecei estudando música nessa banda e desde lá eu fui fazendo apresentações é... dentro da cidade, tocando em procissões, concertos no teatro, e depois mais pra frente eu entrei no conservatório pra aprimorar os estudos na clarineta; e hoje em dia eu estou frequentando o curso de graduação, licenciatura em música com habilitação em clarineta." (M.).

"Música, pra mim, hoje é minha profissão, só que eu faço música porque eu gosto, então é... hoje em dia eu não poderia mais viver sem música, já estou envolvido inteiramente com a música." (M.).

"A maioria ali não vai querer aprimorar, porque tem gente ali que não vai seguir carreira. Tem gente ali que trabalha com uma coisa e sabe que ele não vai se tornar músico profissional, então por que que eles vão ficar querendo correr atrás? Agora, tem gente não, tem gente que tá fazendo orquestra, tá na faculdade, tem uns que já formaram que ainda de vez em quando vão na orquestra porque não têm como ficar indo sempre, mas, acho que a maioria não esquenta muito a cabeça." (R.).
\end{abstract}

\section{CONCLUSÕES}

Considerando as corporações musicais de São João Del Rei como um sistema cultural, verifica-se uma enorme riqueza de atividades, em que orquestras bicentenárias, bandas tradicionais, o conservatório estadual de música, curso de licenciatura em música e apresentações em diversos espaços da cidade têm 
existência concreta e instituída, têm valores e normas específicos, formas particulares de ação, e são objetos de representações múltiplas. As atividades musicais atingem a população como um todo. Cada um, a seu modo, colabora para uma cultura musical variada que atinge de forma particular cada cidadão sanjoanense.

Como sistema simbólico, a música em São João Del Rei tem heróis ilustres, como os pracinhas do $11^{\circ}$ Batalhão de Montanha, que participaram como músicos da Segunda Guerra Mundial, que são lembrados em homenagens diversas, como nomes de ruas, e que receberam monumentos públicos. $\mathrm{Na}$ cidade a música tem ídolos, como o Padre José Maria Xavier (1819-1887), compositor ilustre, conhecido principalmente por suas obras sacras, o qual é uma referência até os dias atuais. Sua obra se incorporou ao imaginário de São João del Rei, identificada por aqueles que frequentam as festividades religiosas promovidas pelas irmandades, confrarias e ordens terceiras (Viegas, 2006). Tradições e ritos musicais são rigorosamente conservados, como os da Semana Santa, quando as missas são celebradas em latim e a presença da música sacra, tocada pelas orquestras, é indispensável nas celebrações. Aliás, as principais atividades das orquestras mais antigas são as celebrações em missas, a Semana Santa e as novenas das igrejas de Nossa Senhora do Pilar e de São Francisco. Esses mitos, ritos e heróis concretizam a ação das corporações, orientando e dando sentido às práticas por elas realizadas. Constrói-se, assim, uma memória coletiva que dá sentido aos projetos musicais, que são mostrados com orgulho à sociedade.

Como sistema imaginário, a atividade musical na região atinge crianças, jovens, adultos e idosos, fazendo parte de suas vidas, de suas memórias, sonhos, afetos e representações, direcionando e alimentando, dessa forma, projetos de vida. Nos grupos musicais, os jovens encontram um espaço de socialização que os distingue socialmente e lhes permite, constantemente, a apropriação e interiorização de valores, normas e costumes adotados pelos grupos de pares. Pode-se dizer, concordando com Enriquez (1997), que dessa forma os jovens satisfazem o desejo de reconhecimento e o reconhecimento de seus próprios desejos.

A pesquisa permitiu descrever o discurso sobre o projeto de vida por meio de enunciados como por exemplo: a música distingue socialmente os músicos; a participação nos grupos cria um espaço de socialização; a música é uma experiência inefável; a música é objeto de ilusões, idealizações e crenças; a música é, também, um projeto de vida. Esses enunciados dão a entender que a música, na ótica desses jovens atores sociais entrevistados, é uma atividade agradável, vital, frequentemente amadora e, eventualmente, construtora de seus projetos futuros. Ela não é necessariamente a atividade central da vida deles, nem projetada como a principal atividade profissional. Ela torna-se componente da subjetividade dos que com ela se envolvem.

A constituição de projetos se dá, inicialmente, no imaginário, muitas vezes por meio de ilusões, idealizações e crenças. Para uns, predomina um imaginário motor, para outros, um imaginário enganoso. Em todos os casos, há um imaginário aberto à mudança, à criatividade, à inovação e ao exercício de autonomia. A fala de um jovem entrevistado fecha este artigo:

\begin{abstract}
"Acho não só eu, mas a maioria, de forma geral, a gente enfrenta é, por exemplo, eu sou flautista, às vezes a gente faz faculdade. Hoje mesmo eu estava conversando com um músico, e ele mesmo falou que fazer faculdade é muito bom, depois que você forma é que está o problema, como você vai arranjar um emprego como flautista. É muito difícil. Ele mesmo disse que o sonho dele era ser um músico de orquestra, mas que já viu muitos concursos de gente boa tocando e ninguém passar. $O$ último concurso que teve em uma orquestra aí, foram não sei quantos flautistas tocarem e ninguém passou, não abriu pra ninguém. Então acho que a dificuldade maior esta é no final: você já formou o curso e aí o que que você vai fazer da vida? E aí você vai dar aula, você segue carreira, você faz um mestrado, doutorado, você tenta dar aula em faculdade ou você tenta ser músico de orquestra, ou nenhum dos dois, você larga a carreira de lado e tenta outra coisa. Acho que a dificuldade maior está aí, porque o músico nunca vai ter um emprego garantido, não dá pra falar "oh, eu vou ser músico de orquestra" ou, "eu vou ser professor de universidade. Acho que isso é uma dúvida que todo mundo tem e isso de forma geral. Acho que essa é a maior dificuldade que a gente enfrenta." (R.)
\end{abstract}

Esse fragmento de discurso foi escolhido porque traduz angústias com relação ao futuro profissional do músico. Ele pode ser transposto para qualquer campo profissional, lembrando-se que as dúvidas enfrentadas pelos jovens que se defrontam com as escolhas podem nortear seu futuro. Não obstante, o que sobressai é a consciência desse jovem de ter um futuro incerto, cheio de dúvidas, incertezas e dificuldades, o que não deixa de ser realista, "pé no chão".

$O$ que se afirma, a partir desta pesquisa fundamentada no imaginário radical, é a possibilidade de um projeto de vida em que o sujeito, inserido no contexto de sua realidade social e psíquica, projeta-se 
no futuro, lança-se em busca de algo a ser realizado, traçado no presente, inacabado, em construção e transformação. Não é necessário que seja um projeto profissional relacionado à música. A experiência na corporação é vivida como uma forma positiva de construção de projetos de vida.

\section{REFERÊNCIAS}

Castoriadis, C. (1982). A instituição imaginária da sociedade. Rio de Janeiro: Paz e Terra.

Castoriadis, C. (1999). Psicanálise e filosofia. In C. Castoriadis. Feito e a ser feito: As encruzilhadas do labirinto $V$ (pp. 153-167). Rio de Janeiro: DP\&A.

Castoriadis, C. (2007). Sujeito e verdade no mundo socialhistórico. Rio de Janeiro: Civilização Brasileira.

Castoriadis, C. (2008). L'imaginaire comme tel. Paris: Éditions Hermann.

Charaudeau, P. (2008). Linguagem e discurso. São Paulo: Contexto, 2008.

Courtine, J.-J.(2009). Análise do discurso político. São Paulo: EdUFSCar.

Enriquez, E. (1997). A organização em análise. Petrópolis (RJ): Vozes.

Enriquez, E. (2001). O vínculo grupal. In M. N. M. Machado, E. M. Castro, J. N. G. Araújo, \& S. Roedel (Orgs.). Psicossociologia: Análise social e intervenção (pp. 61-74). Belo Horizonte: Autêntica.

Enriquez, E. (2008). Entrevista. $O \& S, 15$ (44), 189-195.

Foucault, M. (2008). A Arqueologia do Saber. Rio de Janeiro: Forense-Universitária.

Foucault. M. (2010). A ordem do discurso. São Paulo: Edições Loyola.
Gallo, P. P. V. (1998). "Coalhadas" e "Rapaduras": história social da música em São João del-Rei no século XIX .Monografia de Especialização, PósGraduação em História de Minas do Século XIX, Fundação de Ensino Superior de São João del Rei, São João del Rei, Minas Gerais.

Gonçalves, A. M., \& Vieira-Silva, M. (2009). Afetividade, Identidade, Tradição e suas Articulações na construção de projetos de vida [CD-ROM]. In Anais do VIII Congresso de Produção Científica da UFSJ. São João del-Rei: Universidade Federal de São João del-Rei.

Gregolin, M. R. (2006). Foucault e Pêcheux na análise do discurso. São Paulo: Editora Clara Luz.

Machado, M. N. M. (2010). Discurso da equidade e da desigualdade sociais: significações imaginárias, vínculo social. Belo Horizonte: Editora Argvmentvm.

Machado, R. (2009). Foucault, a ciência e o saber. Rio de Janeiro: Jorge Zahar Ed.

Maingueneau, D. (2007). Gênese dos discursos. Curitiba: Criar Edições.

Maingueneau, D. (2008). Cenas da enunciação. São Paulo: Parábola Editorial.

Sobrinho, A. G. (2002). Bandas musicais de São João delRei e a Banda Teodoro de Faria. Revista do Instituto Histórico Geográfico de São João del-Rei, 10, 12-23.

Viegas, M. S. R. (2006). O solo de flauta do IV responsório das matinas de natal do Padre José Maria Xavier: aspectos históricos, estéticos e interpretativos. Dissertação de Mestrado, Universidade Federal de Minas Gerais, Belo Horizonte.

Recebido em 04-11-2011

Aceito em 14-05-2012
Endereço para correspondência:

Aline Moreira Gonçalves. Avenida Padre Teodoro Ground, 10, Esquina com Maringá, Bairro Aeroporto Industrial, CEP 35701-302, Sete Lagoas-MG, Brasil. E-mail: linemgoncalves@ yahoo.com.br. 